\title{
Learning Styles And The Online Classroom: Implications For Business Students
}

Michael Nastanski, Saint Leo University, USA Thomas Slick, La Verne University, USA

\begin{abstract}
This paper discusses the importance of student learning styles within a Distance Learning (DL) classroom. The study examines the learning style preferences of online business students as measured by the Kolb Learning Style Inventory and determines if a significant difference in course grades and course completion rates exist between students when they are sorted by learning style preference. Subjects in the study were 344 online business students from a southeastern university in the United States. Examination of the quantitative data indicated a significant difference existed for Diverger Style Preference learners compared to the Assimilator, Accommodator and Converger learning styles. They had a lower Mean Grade Point (GP) earned. The study revealed approximately one out of five (20\%) of the respondents had a Diverger Learning Style Preference. Respondents with this learning style preference appear to be somewhat less likely to be successful in a distance learning environment. A Chi Square calculation showed no significant difference existed among learning styles for those dropping a course although one group (Accomodators) had approximately twice the drop rate of the others. This paper and corresponding study offers university administrators who seek to maintain quality instruction evidence and suggestions for addressing 20 percent of their online population who may be at risk of not obtaining content mastery. This includes implications for DL course design and pedagogy.
\end{abstract}

Keywords: Learning Styles, Kolb, Distance Learning, Pedagogy, Diverger, Accommodator, Assimilator, Converger

\section{INTRODUCTION}

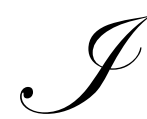

n 2002, the National Center for Educational Statistics (NCES) reported between the years 2000 and 2013 there would be an increase of 18 percent in enrollment in public degree granting institutions (NCES 2003). The same report reveals that the number of people earning postsecondary degrees will dramatically increase. In order to teach more students without building more classrooms, postsecondary institutions need to increase information technology tools and support, such as online learning. To meet this challenge, effective Distance Learning (DL) needs to creatively utilize computer technology and improve methods of delivering instruction. A problem exists if traditional brick and mortar institutions cannot supply the training and education required by the workforce to meet this challenge.

An increasingly popular and effective way to meet the increasing demand for higher education has come in the form of distance education or distance learning. The field of offering coursework outside of a traditional classroom setting has grown rapidly in the past decade, especially as many colleges have begun offering courses and degree programs via the Internet or World Wide Web (Carnevale 2005). Distance learning allows colleges to expand their course offerings without the capital expenditures associated with additional classroom space, while providing current students and new students the flexibility to take courses within the constraints of their busy lives (Johnson et al. 2003).

According to the academic leaders of more than 1,100 colleges and universities, about 2.6 million U.S. college students were enrolled in online course in the fall of 2004 (Trotter 2004). Slightly more than half of all colleges rated online learning as essential to their overall strategy. The benefits of distance learning are numerous. 
Those looking for alternatives to the traditional campus experience, with family obligations, geographic barriers, or physical limitations find it appealing that they can earn degrees from their homes (Vivoda 2005). Distance learning enables communication with geographically and culturally dispersed peers, provides the ability to glean from experts otherwise unreachable, and transcends limitations of time, distance, and money. Its unique environment allows time and location flexibility, cost and time conservation, self-paced learning, a collaborative learning environment, and unlimited use of learning material (Zhang and Zhou 2003). A problem exists when institutions do not properly address these diverse populations in their course design particularly as it relates to learning styles.

Currently, the majority of distance learners are over twenty-five years old, have full-time careers, female, and shoulder family and civic responsibilities (Tonkin 2003). Additionally, those participating in distance learning courses may have different prior learning experiences, coping strategies, and different learning styles and preferences (Dzakiria 2005). Research conducted by Henry O'Lawrence (2006) reveals that the majority of studies report no significant differences between DL and traditional modalities. He concludes that it is the instructional strategies, not technology, that make a difference in how adults learn online. Instructional methods need to generate interest and provide meaning for adult learners.

When designing a DL course, Pallof and Pratt (2003) recommend that instructors understand their cliental, how they learn, issues affecting their lives and learning, and how students can be supported during the learning process. Though Pallof and Pratt mention understanding how student learning is important, they do not address the role individual learning styles may play in enriching a successful DL environment. This creates a problem when course design fails to address all possibilities to effectively deliver content.

The increased trend toward usage of DL poses significant questions. Universities are offering it and businesses requiring it, but is everyone ready to benefit from DL? With over thirty years in the field, DL educator Michael G. Moore states, "Most of what is happening in the name of distance education is simply traditional pedagogy and traditional structures of higher education with the addition of new technology" (1996). Though technology provides flexibility for distance learners, it also produces challenges such as adapting to the self-directed nature of the learning environment (DeTure 2004). If distance learning instructors wish for their students to succeed, they need to create an educational environment that capitalizes on they way they learn best (Dzakiria 2005). Limited information exists on what accounts for individual student differences when taking online courses (Wojciechowski and Palmer 2005). Research is needed to generate understanding of what kinds of learners are likely to succeed in a DL environment.

Fostering success of online courses will come from research seeking to identify variables facilitating or impeding persistence in DL educational environments (Dupin-Bryant 2004). In an era or lifelong learning, continued research is needed to help practitioners of distance learning develop approaches which support and validate learners' involvement and investment in their own learning. Experiences that enhance the development of individual learners, whatever their background, would help develop a distinctive identity for distance learning (White 2005).

Addressing this issue can be accomplished by analyzing learning style preferences of students in DL courses and reviewing implications for alternative instructional models that can be generated (Bender, Wood, and Vredevoogd 2004). As distance learning is student centered, understanding the personal characteristics of students is an important component to overcoming possible barriers to learning. Research that focuses on the positive relationship of grade point average and successful completion of DL courses would help develop a greater appreciation of these issues and enrich the planning of DL coursework and instructional strategy (Jefferson 2005). Research indicates that in distance learning environments it is good practice for online instructors to incorporate students' learning styles into pedagogical design of their courses to maximize student success (Du and Simpson 2002). A 2004 study reviewed articles published in four prominent DL journals between 1997 and 2002, recommending a more critical examination of the dynamic characteristics of learner populations (Lee, Driscoll, and Nelson 2004). Instructors need to pay attention to these issues if they hope to engage every member of their group, achieve learning objectives, and form a solid and successful learning community (Pallof and Pratt 2003). This study will contribute to the body of literature addressing the role learning styles play in a DL environment. The purpose of 
this study was to examine the learning style preferences of online business students as measured by the Kolb Learning Style Inventory and determine if a significant difference in course grades and course completion rates exist between students when they are sorted by learning style preference. Research conducted by Wang, Foucar-Szocki, and Griffin (2003) indicates the current dropout rate is 26 percent for DL students.

The need to know whether or not learning styles play a significant role in the success of distance learners benefits a variety of stakeholders, including faculty, students, and parents. The knowledge obtained will be significant for instructors, administrators and companies seeking to design more effective DL courses. Additionally, students, guidance counselors, faculty, and parents seeking successful learning environments will gain greater insight whether or not DL is an efficient and effective educational environment for their individual needs.

\section{LITERATURE REVIEW}

\section{History Of Distance Learning}

The practice of distance learning (DL) is not new. The earliest forms of DL were correspondence courses, or home study, mailed by private and for-profit schools. In the United States, it has been documented as early as the 1700s that present-day distance education was advertised first as courses offered by mail and labeled "correspondence study" (Holmberg 1995).

During the late nineteenth and early twentieth centuries, DL took the form of correspondence courses and independent study programs. The first forms of technologically stimulated DL in the United States were generated by radio and film. In the 1920s, the Wisconsin School of the Air became the first American DL program to capitalize on this new form of technology, allowing prominent intellectuals to lecture to thousands rather than hundreds of students at one time (Prewitt 1998).

In the 1950s, the Ford Foundation proceeded to serve as the single greatest benefactor of educational television (ETV). By 1962, the Educational Television Facilities Act (Public Law 87-447) was approved by Congress. This marked the first time millions of dollars from the federal government were directed into building and improving physical facilities for educational communication. Western Reserve University became the first institution to offer a continuous series of TeleCourses, followed by New York University who broadcasted "Sunrise Semester" on CBS from 1957 to 1982 (Simonson et al. 2000).

During the 1970s, universities began offering lecture-formatted courses on television supplemented by small group meetings with teaching assistants. The Organization of American States invested huge sums of capital in the 1970s attempting to deliver education to remote areas of El Salvador, Brazil, Colombia, and Mexico (Prewitt 1998). The 1970s also witnessed the founding of Open University in the United Kingdom. Previously, DL had been offered by small, private, correspondence schools. The demand for new DL universities grew with other countries' need for additional postsecondary education and an adult population with increasing work and family responsibilities (Holmberg 1986).

It was during this time that governments throughout the world had begun to see DL as an opportunity to achieve national development goals, such as improving worker qualifications to successfully acclimate to a new economic climate and generate access for those who previously had been excluded from educational opportunities. Australia and Canada's British Colombia established open universities to coordinate DL offerings to improve educational access throughout worker's lives. International development agencies such as the Asian Development Bank in 1987 embraced DL as a way to address educational needs in developing countries (Calvert 2005).

Fiber optic technology in the late 1980s and early 1990s enabled the expansion of quality live two-way audio and video systems. The Iowa Communications Network (ICN) provided two-way interactive video, Internet, and voice services for over six hundred classrooms and 100,000 hours of monthly broadcasting (Bates 1995). 
In the 1990s, the Institute for Higher Education policy contracted Ronald Phipps and Jamie Merisotis to review research on the effectiveness of DL in higher education. Phipps and Merisotis (1999) indicated that DL changed significantly in the 1980s when computer-assisted instruction and other forms of educational technology became more widespread and were utilized by colleges and universities. They also conveyed that during the 1990s computer-mediated communication and a variety of other technologies significantly changed DL. These technologies included one-way or two-way synchronous video, two-way audio/one-way audio, computer mediated learning, web-based asynchronous methodologies, and one-way prerecorded video. As personal computers and the Internet gained more widespread use in the late 1990s, more people were able to pursue education from a distance than ever before (Chan and Welebir 2003). This technology has fueled the consumer market for DL and created opportunities for universities to address it.

The demand for distance education availability, course offerings, and enrollment increased rapidly during the 1990s. The National Center for Education Statistics reported 91 percent of public four-year institutions and approximately 50 percent of all private institutions, constituting nearly 1.6 million students, were currently offering, or planning to offer distance education programs. Many of these programs are currently or will be offered in an online learning environment). By 2003, the number of four-year public universities offering DL had grown to 89 percent, while 90 percent of two-year public schools offer distance education courses (Carnevale 2005).

According to Michael G. Moore and Greg Kearsley (1996), DL has evolved through three generations as depicted in figure 1.

Fig. 1. Evolvement of distance learning

\begin{tabular}{|l|l|}
\hline $\begin{array}{l}\text { Correspondence/Independent Study: Students study at home and interact with instructors through } \\
\text { postal mail service. }\end{array}$ & $1^{\text {st }}$ Generation \\
\hline Open Universities: A Nationwide University System with no resident students. & $2^{\text {nd }}$ Generation \\
\hline $\begin{array}{l}\text { Broadcast (radio \& television) and Teleconferencing: Radio and television transmissions and } \\
\text { videoconferencing via one-way-video-two-way-audio communications. }\end{array}$ & $2^{\text {nd }}$ Generation \\
\hline Networks/Multimedia: Computers and networks of computers linked by telecommunications. & $3^{\text {rd }}$ Generation \\
\hline
\end{tabular}

The National Education Association (NEA 2002) Policy Statement number 13 defines DL as a form of education in which courses are delivered via the Internet (or other forms of digital technologies evolving from the Internet as it exists today) without face-to-face interaction between student and instructor; and the United States Distance Learning Association (USDLA 2006) provides a more succinct definition, "The acquisition of knowledge and skills through mediated information and instruction, encompassing all technologies and other forms of learning at a distance" .

From its infancy in the early 1700 s to the present day, DL has provided opportunities for those not able to access traditional forms of education. The development of technologies has generated new ways to design programs and provide a myriad of choices to prospective students. This has significantly expanded access to higher education for students around the world.

\section{Distance Learning Last Five Years}

In 2004, the Sloan Survey of Online Learning revealed that online enrollments continued to grow at faster rates than the broader student population with enrollment increasing from 19.8 percent in 2003 to 24.8 percent in 2004. Currently, 89 percent of four-year public universities and 90 percent of two-year public schools offer distance education courses (Olson et al 2004). Merrill Lynch predicts that the online learning market will soon approach \$25 billion. The driving forces behind this phenomenon are convenience, access, flexibility, availability, and the ability to learn anytime and anywhere (Devi 2001). 
A meta-analysis of the comparative distance education literature between 1985 and 2002 discovered 232 studies containing 688 independent achievement, attitude, and retention outcomes, which indicated that classroom instruction and distance education were comparable and suggested that applications of distance education outperform their classroom counterparts (Bernard et al. 2004).

If instructors are to embrace DL, it is critical that they incorporate specific learning styles and cognitive styles into educator training designs. This will enable educators to benefit by recognizing learning and cognitive style differences and to be equipped with the knowledge, skills, and strategies to address differences (Buck 2003).

Just as in face-to-face classroom setting, a quality DL program requires preparation and good pedagogy. Quality education, whether in the classroom or online, utilizes a variety of teaching techniques. The planning of quality, active learning strategies promotes optimal learning and enhances online learning during all phases of the teaching-learning process, accommodating a variety of learning styles (Phillips 2005). Student satisfaction with online instruction is influenced by their positive perceptions of technology in terms of ease and access, the use of flexible learning material, and autonomous and innovative learning styles (Drennan, Kennedy, and Pisarski 2005).

Barriers to successful online learning include administrative issues; lack of social interaction, academic, and technical skills; learner motivation; time and support for studies; cost and access to the Internet; and technical problems (Muilenburg and Berge 2005). These barriers can be addressed by creating methods of online instructor immediacy that adapt to the characteristics of Web-based culture, online students, content area, and student's learning styles (Kim 2005). To do this effectively requires a fundamental understanding of how people acquire knowledge.

\section{Learning Acquisition}

Literature reveals diverse definitions of learning theory. Some schools of thought view learning in terms of cognition, while others perceive learning in terms of social interaction or experiential constructs. Several dominant theories on learning are described to provide a broader scope of understanding how people acquire information.

Early theories of learning in western civilization (Hergenhahn and Olson 2001) can be traced back to the early Greeks. Plato believed knowledge was inherited. He contended that knowledge was gained by reflecting on the contents of one's own mind. Additionally, Plato believed knowledge was innate, categorizing him as a nativist. Aristotle extolled that knowledge was derived from sensory experience and was not innate. Empiricism applies here, stressing the importance of sensory experience. Charles Darwin combined elements of Plato and Aristotle, supporting biological evolution. His theories enabled human nature to be considered a combination of both biological heritage and life experience.

Darwin's writings strongly influenced functionalistic theorists such as Edward Lee Thorndike. He was the first to observe, under controlled conditions, the consequences of behavior produced by a backward-acting effect on the strength of that behavior. Additionally, Thorndike believed educational practices should be studied scientifically.

The functionalists laid a foundation for the next generation of learning theorists; behaviorists. Founded by John Watson in the 1920s, they believed all human behavior is the result of a person's prior conditioning and is determined by external forces in the environment over which a person has little or no control (Elias and Merriman 1995). All behaviorists reach the same conclusion about education; it must be individualized (Hergenhahn and Olson 2001).

B. F. Skinner developed applied scientific psychology that could easily be applied to animal training and human behavior modification therapy (Hergenhahn and Olson 2001). Skinner insisted that objectives be defined behaviorally and stressed the importance of what students were doing while learning. Skinner and all other behaviorists would prescribe a learning environment allowing for individual differences in learning rate. They would prefer to deal with students individually or design course material allowing them to work at their own pace. 
Associationistic Theorists, the most notable being Ivan Petrovich Pavlov, believed that relationships among ideas were explained by the laws of association. The first to develop anticipatory learning, he believed stimuli cause and reinforce behaviors. Students could develop a lifelong love or aversion to education based on their positive or negative experiences in the classroom.

Cognitive theorists contended that organisms at any given time can interact with the physical environment and cognitive structure results from biological maturation and cumulative experience (Hergenhahn and Olson 2001). This includes Gestalt Theory, which stresses meaningfulness and understanding as important components in learning. Students must see parts as being related to the whole and learning takes place when they understand, not memorize information. Jean Piaget urged that educational experiences be built around the learner's cognitive structure and include the dual processes of assimilation and accommodation. This would require teachers to know the level and functioning of each child's cognitive structure.

Individualized instruction and competency-based education are based on behaviorist principles (Pattison 1999). This generated the humanist movement, those concerned with the development of the whole person. They believe education should be student centered and the relationship between teacher and student is critical to the learner's development.

Benjamin Bloom's taxonomy of educational objectives is organized in a hierarchical fashion. Based on learner behaviors, each new skill acquired stems from one attained from the previous level of the taxonomy. Both knowledge and comprehension are necessary to the application of knowledge when attempting to solve problems. Learners must master the knowledge class of the domain for correct application of knowledge to occur. This requires that they possess the ability to recollect and recognize information. Once they successfully meet knowledge objectives, comprehension must be mastered, requiring conversion, clarification, and extrapolation of information based upon the learner's ability to understand the literal and abstract message of the intended content. When these two behaviors can be successfully demonstrated, the learner will be able to apply knowledge to a variety of different situations (Bloom 1956).

Malcolm Knowles (1984) proposed that education should meet the needs of students and be student centered. He contended that lifelong learning skills would be promoted if schools organized curriculum around student needs. Additionally, adults are more ready to learn when educational content is relevant to learner's needs.

Carl Rogers (1969) developed a person-centered theory and explored the notion of student-centered teaching. The approach focuses on a relationship with a central goal of facilitating people's movement along a path toward trust and ability to be in the present moment.

\section{Learning Styles}

The foundations of modern leaning style approaches can be traced back to constructivism, spawned by the works of psychologist Jean Piaget. Constructivist philosophy contends learners construct their own knowledge individually and collectively (Bütün 2005). Piaget's Cognitive Constructivism dates back to the early 1920s where he contended that a child constructs understanding through many channels such as reading, listening, exploring, and experiencing their own environment (Piaget 1977). He defined learning in four stages of development: sensor motor, preoperational, concrete operation, and formal operation.

A way to explore academic success beyond the issues of intelligence is to analyze a student's learning style. The manner in which individuals choose or are inclined to approach learning situations impacts the performance and achievement of learning outcomes (Cassidy 2004). According to Richard Riding and Indra Cheema (1991), learning style seems to have emerged as a more common or replacement term for cognitive style in the 1970s. Learning styles are considered stable over time, but the structure can be responsive to experiences that allow change to enable adaptive behavior (Cassidy 2004). 
Research analyzing citation rates of authors cited together in cognitive and learning style literature since 1972 reveal that David A. Kolb is the most cited author in learning style literature (Desmedt and Valcke 2004). Kolb's (Kolb and Kolb 2005) learning style theory suggests that individuals prefer to receive or take information by "doing" or "reflecting." Once information is received, people prefer to process it by "experiencing" or "thinking." From these learning preferences, Kolb and Kolb (2005) sorts people into four different types of learning styles.

1. Divergers: Individuals with this style have concrete experience (CE) and reflective observation (RO) as dominant learning abilities. People with this learning style are best at viewing concrete situations from many different points of view but prefer observation over action.

2. Assimilators: Those with the ability to combine elements of reflective observation (RO) and abstract conceptualization (AC). People with this learning style are best at understanding a wide range of information and putting it into concise, logical form. They tend to focus more on ideas, concepts, and logic than personal needs.

3. Convergers: Those with the ability to combine elements of abstract conceptualization (AC) and active experimentation (AE). People with this learning style prefer practical uses for ideas and theories and tend to be leaders that work well in pressure situations. They tend to deal with technical tasks rather than social or interpersonal issues.

4. Accommodators: Those with the ability to combine elements of active experimentation (AE) and concrete experience (CE). People who learn best when dealing with "hands-on" situations or tasks. They enjoy carrying out plans, involving themselves in new experiences and tend to act on 'gut' feelings rather than logical analysis.

Student success is critical to educational stakeholders. Assessing student success takes many forms. Graham Gibbs states the importance of quality and quantity of time studying play in student learning. Assessment of students, such as at the end of course exams and projects, is the "primary influence" on student learning, ensuring that they spend time learning the material (Gibbs 2003). He believes a high score on an end of a course exam or high grade earned has a positive influence on the quality of learning undertaken and low scores demonstrating the opposite.

When predicting DL success, prior achievement is still the best predictor of future achievement (Bernard et al. 2004). In a study that developed a predictive validation instrument assessing achievement outcomes of DL learning success, it was concluded that cumulative grade point average (GPA) is the best predictor of how a student will perform in an online environment.

The social interaction of people is a common thread binding learning theories together. Piaget's need for social process, Knowles focus on meeting unique needs and Rogers's theory of student-centered learning is built upon relationships; all point to individuals possessing their own unique form of processing information. How that information is processed, assessed, and considered successful can, in part, be measured by course completion and grade earned. This study provides greater insight into how students construct knowledge and experience success differently. What follows is a more detailed analysis of this in a DL environment.

\section{Learning Styles And Distance Learning}

Significant differences were found between the learning style preferences of online students and face-toface students by researchers using three different learning style instruments (Aragon, Johnson, and Shaik 2002). When investigating possible correlations between students' learning styles, computer competency, and student satisfaction in web-based learning, a significant difference existed among different learning styles regarding student satisfaction level when the computer competency level of subjects differ. Using the Kolb Learning Style Inventory, accommodating and diverging styles demonstrated a higher level of computer competency results and a higher level of student satisfaction, with converging and assimilating styles revealing a lower level of computer competency and student satisfaction (Du 2003). 
In 1991, Dille and Mezack used Kolb's Learning Style inventory to predict student's success in community college telecourses. They found students who score high on preferring abstract or conceptual analyses tend to be more successful in distance learning situations. Additionally, students who had a high need for concrete experiences and interactions with peers and the teacher would be at risk for failure in distance learning courses (Dille and Mezack 1991).

Learners come from a variety of backgrounds requiring attention to different learning needs and active learning strategies addressing different learning styles (Phillips 2005). Methods and strategies need to be employed in the design of web-based learning environments that help bridge learners and reduce feelings of alienation. Until designers of DL apply learning theory, learning styles, and design features to the production of the product, thinking will remain at the knowledge and comprehension cognitive levels (Notar, Wilson, and Montgomery 2005). Assessing the efficacy of technology to meet diverse and emerging individual learner and learning community needs is critical. (McCombs and Varilli 2005, 1595)

Designing successful DL courses from a constructionist or behaviorist perspective requires the appropriate delivery system based on the benefits of the medium, course content, and needs of the learner, not only the convenience of the designer or instructor, but focusing on the learning and the learner (Berge 2002). Instructors cannot view learners as customers. They need to develop learner-centered and learner-driven activities to engage DL participants and ensure successful learning (Chernish et al. 2005). This study contributes to addressing that need.

Howell, Laws, and Lindsay's (2004) review of DL literature indicates that little or not data exist on completion rates and what is available is suspect. They concluded that the unique characteristics, needs, and motivations of students to select DL over traditional face-to-face instruction are not easily compared and no standardized algorithm for calculating completion rates currently exists in higher education. This study moves toward addressing this need. Baab (2004) determined that both students and teachers should be made aware of a student's learning style preference at the beginning of a distance learning course, preferably in the orientation. Baab suggests that providing this information to DL participants enables them to adapt or accommodate their learning style preference for the level and type of interactivity, teaching style, and design for delivery of DL courses. This study moves toward addressing this need.

\section{THE STUDY}

The purpose of this study was to examine the learning style preferences of online business students as measured by the Kolb Learning Style Inventory and determine if a significant difference in course grades and course completion rates exists between students when they are sorted by learning style preference.

\section{Research Questions}

1. What is the distribution of learning styles in a distance learning format?

2. What are the mean grade points (GP) earned and completion rate in a distance learning environment?

3. What are the mean grade points (GP) earned and completion rate for the Assimilator Style preference learner?

4. What are the mean grade points (GP) earned and completion rate for the Accommodator Style preference learner?

5. What are the mean grade points (GP) earned and completion rate for the Converger Style preference learner?

6. What are the mean grade points (GP) earned and completion rage for the Diverger Style preference learner?

7. Is there a significant difference in grade points (GP) earned and completion rate when sorted by learning styles? 


\section{Design Of The Study}

This descriptive study looked for differences between mean grade points (GP) earned and course completion rates of distance learning (DL) courses when sorted by learning styles measured by the Kolb Learning Style Inventory.

The study was undertaken in two phases. The first phase invited respondents to participate in an online survey to determine their learning style preference. The Kolb Learning Style Inventory-Version 3.1: 2005 Technical Specifications (Kolb and Kolb 2005), a twelve- question instrument, was used to gather qualitative data and sort it into one of four learning style preferences. The second phase used student identification and course numbers to sort quantitative data by course completion rate and individual grades earned to generate group mean grade points (GP) earned. Both phases are illustrated in the figure 2.

Fig. 2. Phases of study

Phase 1: Gathering Qualitative Data

Identify respondents learning style preference according to the Kolb Learning Style Inventory (3.1) and sort them into one of four groups

1. Accommodator Learning Style Preference

2. Assimilator Learning Style Preference

3. Converger Learning Style Preference

4. Diverger Learning Style Preference

Phase 2: Gathering Quantitative Data

1. Sort student data by individual grades and course completion rate.

2. Calculate Mean Grade Points (GP) earned.

3. Determine if a significant difference in Mean Grade Points (GP) earned and course completion rate exists when sorted by learning styles.

\section{Population And Sample}

The study surveyed 1,687 DL students from a southeastern university. This school was selected because of its size and diverse student population. The online classes are hosted on Web CT-based platform, which is one of the top two global DL environments. Students and teachers are provided with remote Internet access to Web CTbased coursework and communication tools which facilitate ongoing, asynchronous interaction between instructors and students. The combination of having a large DL university with one of the predominant tools (Web CT) offers a reasonable sampling environment for this study. All participants were volunteers with equal opportunity to participate. No incentives were offered. Students enrolled were all adults, typically age twenty-three and above, with a mixture of undergraduate and graduate students. The population was primarily business disciplines and enrolled in many different courses. Students are dispersed globally, the majority located in the southeastern United States, and include both civilian and military personnel.

The following criteria were used for the sample:

1. Students were enrolled in a semester class.

2. Students participated in an online survey to determine their learning style preference.

3. Students completed a course and received a letter grade of A, B, C, D, or F.

4. Students who dropped a course did not receive a letter grade.

During the semester the study was launched, 1,687 students were enrolled in DL classes. From that pool, 344 respondents logged onto a website and participated in an online assessment of their learning style preference. 
Of the 344 respondents to the survey, 322 completed a semester course and earned a letter grade. Twenty-two respondents completed the online survey, but dropped a course and did not earn a letter grade.

\section{Instrumentation}

Survey data collected in this study used version 3.1 of the Kolb Learning Style Inventory (LSI) and a Student Record Survey. Revised in 2005, it is the latest revision of the original Learning Style Inventory developed by David A. Kolb and, like its predecessors, is based on experiential learning theory designed to help individuals identify the way they learn from experience (Kolb and Kolb 2005). It is a self-descriptive, twelve-item randomized self-scoring survey asking respondents to rank four sentence endings that correspond to the four learning modes; Concrete Experience (CE), Reflective Observation (RO), Abstract Conceptualization (AC), and Active Experimentation (AE). The LSI is a forced-choice format that ranks an individual's relative choice preferences among the four modes of the learning cycle (Kolb and Kolb 2005). The Kolb Learning Style Inventory-Version 3.1 2005 Technical Specifications Manual (Kolb and Kolb 2005) places them into one of four categories (as previously described): Divergers, Assimilators, Convergers or

\section{ACCOMODATORS}

Easy instructions enable this instrument to be self-administered. Reported inter-rater reliability for the instrument ranges from .71 to .86 , and from .91 to .99 (Garland 2002). Version 3.1 of the LSI has a twelve-item randomized self-scoring format. It also possesses improved psychometric properties, improved test-retest reliability and internal reliability. Its foundation in adult learning research and experimental learning theory enables the LSI to adequately address distance learning styles. A Student Record Survey was designed to record student and course numbers, mean grade points (GP) earned, completion rate, and student learning style.

\section{Data Collection Procedures}

The researchers contacted the Hay Group in the summer of 2005 and obtained permission to use an online version of the Kolb Learning Style Inventory. The Hay Group provided a website to access the Kolb Learning Style Inventory.

An e-mail letter was sent to students explaining the study, requesting student participation, and giving instructions on how to access the Kolb Learning Style Inventory. No inducements were offered to those participating in the study. Students were offered an opportunity to see their survey results. Upon request, they were provided their learning style preference and a description of what it meant.

Participants were provided a website address to access. Instructions then requested they enter a user name and student number as a password. These identification numbers were used to gather data for grades earned and course completion rate. After entering a username and student number, students completed the twelve question Kolb Learning Style Inventory. Every student had an equal opportunity to participate. After each student completed the survey, the Hay Group would e-mail the student's username and learning style preference to the researcher.

\section{GATHERING STUDENT RECORD DATA}

Mean grade points (GP) earned were recorded and analyzed for differences according to learning styles.

Data were collected and analyzed by the following criteria:

1. Grade earned. The specific letter grade earned by each student.

2. Mean Grade Point earned was tabulated for each of the four learning style preferences.

3. Course completion rate. The number of students not completing a course for letter grade were tabulated and sorted by learning style preference. 
Data were collected in the fall of 2006 and sorted by student identification number, learning style preference and letter grade earned. In order to determine if a significant difference existed, a one-way analysis of variance (ANOVA) a test was conducted to find out whether or not significant differences in means are present for one dependent variable being influenced by an independent variable based on the numerical translation of letter grades (Goehring, 1981).

In order to determine what pair or pairs of means were significantly different, two tests were performed. First, a Tuckey's Honestly Significantly Different (HSD) Post Hoc Pair-Wise comparison procedure was selected because it divides all obtained means into subgroups and utilizes a standardized range for a comparison of the means (Isaac and Michael 1995).

A chi-square calculation was then used to determine whether or not a significant difference existed among learning styles for participants who dropped a course. A chi-square addresses questions about data existing in the form of frequencies, not scores or measurements along some scale (Isaac and Michael 1995).

\section{Findings}

The online version of the Kolb Learning Style Inventory-Version 3.1 was offered to 1,687 DL students from a southeastern university. There were 344 total respondents who completed the survey and determined one of four possible learning style preferences. Of those 344 respondents, 322 completed a course and earned a letter grade. Based on the data collected, these are the findings:

\section{RESEARCH QUESTION 1}

\section{What is the distribution of reported learning styles in a distance learning format?}

Of the 344 respondents who completed an online survey and determined a learning style preference, the distribution of learning styles was as follows:

1. Accommodators (104) 30.2 percent

2. Convergers (91) 26.5 percent

3. Assimilators (80) 23.3 percent

4. Divergers (69) 20.0 percent

Nearly a quarter, 80 respondents (23.3 percent), identified themselves as having an Assimilator Style learning preference. Respondents with this learning style preference are best at understanding a wide range of information and putting it into concise, logical form. They tend to focus more on ideas, concepts, and logic than personal needs.

Almost a third, 104 respondents (30.2 percent), reported an Accommodator Style learning preference. These respondents are learners who tend to do best when dealing with "hands-on" situations or tasks. They enjoy carrying out plans, involving themselves in new experiences and tend to act on "gut" feelings rather than logical analysis.

Slightly more than a quarter, 91 respondents (26.5 percent), reported a Converger Style learning preference. Converger Style preference learners are those who prefer practical uses for ideas and theories and tend to be leaders who work well in pressure situations. They tend to deal with technical tasks rather than social or interpersonal issues.

One-fifth of the respondents, 69 (20.0 percent), reported a Diverger Style learning preference. Individuals with this style are best at viewing concrete situations from many different points of view but prefer observation over action. 


\section{RESEARCH QUESTION 2}

What are the mean grade points (GP) earned and completion rate in a distance learning environment?

There were 344 respondents who completed an online survey and determined a learning style preference. A mean grade points (GP) earned of 3.2 was generated by 322 respondents who completed a course and earned a letter grade. A vast majority, approximately 19 out of every 20 (93.6 percent), of the 322 respondents to the online survey completed a course. A small number, slightly more than one in twenty of the respondents, 22 (6.4 percent), did not complete a course and earn a letter grade.

\section{RESEARCH QUESTION 3}

What are the mean grade points (GP) earned and completion rate for the Assimilator Style preference learner?

Of the 344 respondents, 80 (23.3 percent) identified themselves as having an Assimilator Style Learning preference. A mean grade points (GP) earned of 3.4 was generated by the 78 respondents to the online survey who completed a course and identified as an Assimilator Style preference learner. This was slightly higher than the mean grade points (GP) earned of 3.2 for all respondents to the online survey who completed a course and earned a letter grade. Of the 80 respondents to the online survey who identified as an Assimilator Style preference learner, 78 completed the course for a completion rate of approximately $97 \%$.

\section{RESEARCH QUESTION 4}

What are the mean grade points (GP) earned and completion rate for the Accommodator Style preference learner?

Of the 344 respondents there were 104 (30.2 percent) respondents who reported an Accommodator Style learning preference. A mean grade points (GP) earned of 3.1 was generated by the 94 respondents to the online survey who completed a course and identified as an Accommodator Style preference learner. The mean grade points (GP) earned (3.1) for Accommodator Style preference learners completing a course is slightly lower than the mean grade points (GP) earned (3.2) for all respondents to the online survey.

Of the 104 respondents to the online survey who identified as an Accommodator Style preference learner, 94 completed the course for a completion rate of $90 \%$. Nearly half (10 of 22), or 45.5 percent, of the respondents to the online survey who dropped a course reported an Accommodator Learning Style.

\section{RESEARCH QUESTION 5}

What are the mean grade points (GP) earned and completion rate for the Converger Style preference learner?

Of the 344 respondents there were 91 (26.5 percent) who reported a Converger Style learning preference. A mean grade points (GP) earned of 3.3 was generated by the 86 respondents to the online survey who completed a course and identified as a Converger Style preference learner. The mean grade points (GP) earned by Converger Style preference learners (3.3) was slightly higher than the mean grade points (GP) earned (3.2) for all respondents to the online survey who completed a course.

Of the 91 respondents to the online survey who identified as a Converger Style preference learner, 86 completed the course for a completion rate of approximately $94 \%$. Nearly one out of four, or 22.7 percent, of the respondents to the online survey that dropped a course reported a Converger Learning Style preference for a completion rate of 


\section{RESEARCH QUESTION 6}

What are the mean grade points (GP) earned and completion rate for the Diverger Style preference learner?

Of the 344 respondents, there were 69 (20.0 percent) who reported a Diverger Style learning preference. A mean grade points (GP) earned of 2.7 was generated by the 64 respondents to the online survey who completed a course and identified as a Diverger Style preference learner. The mean grade points (GP) earned of 2.7 for Diverger Style preference learners is lower than the mean grade points (GP) earned of 3.2 for all respondents to the online survey that completed a course.

Of the 69 respondents to the online survey who identified as a Diverger Style preference learner 64 completed the course for a completion rate of approximately $93 \%$.

\section{RESEARCH QUESTION 7}

Is there a significant difference in grade points (GP) earned and completion rate when sorted by learning styles?

The data in table 1 show the number of respondents who completed a course when sorted by learning style, and a one-way table of their mean grade points earned and standard deviations for the four learning styles.

The data in table 1 show that of the 322 respondents who completed a course and earned a letter grade, 94 (29.2 percent), reported an Accommodator Learning Style preference with a mean grade points (GP) earned of 3.15 and a standard deviation of .961. There were 78 (24.2 percent) students who reported an Assimilator Learning Style preference possessing a mean grade points (GP) earned of 3.37 and a standard deviation of .779. An additional 86 (26.7 percent) who reported a Converger Learning Style preference had a mean grade points (GP) earned of 3.30 and standard deviation of .714. There were 64 (19.9 percent) students who reported a Diverger Style learning preference with mean grade points (GP) earned of 2.70 and standard deviation of 1.237.

Table 1

Respondents Who Completed a Course When Sorted by Learning Style, Their Mean Grade Points Earned, and a OneWay Table of Means and Standard Deviations for the Four Learning Styles

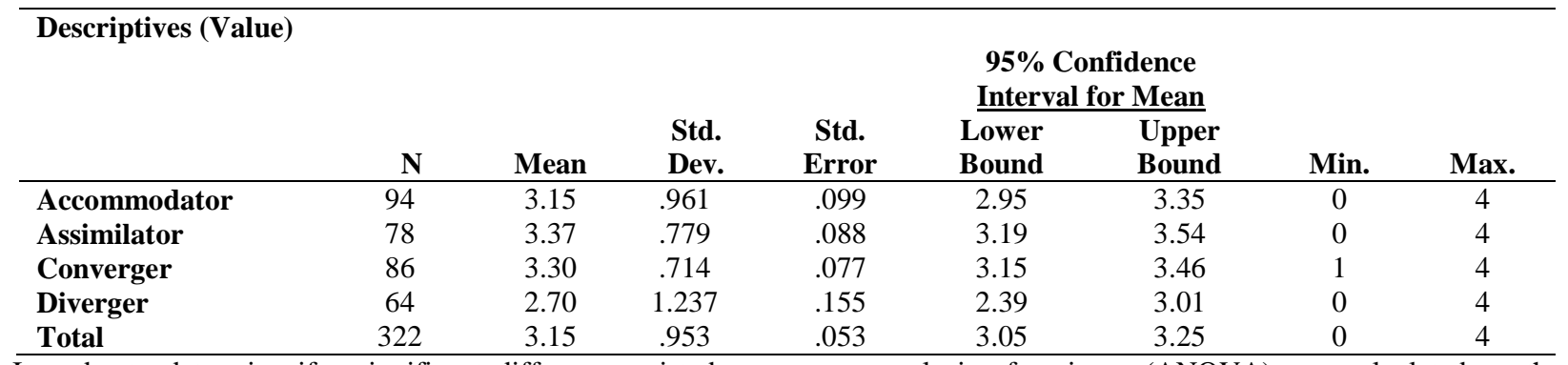

In order to determine if a significant difference existed, a one-way analysis of variance (ANOVA) was calculated on the numerical translation of letter grades. Table 2 shows the ANOVA calculation conducted to determine if a significant difference existed. 
Table 2

ANOVA Calculation for Significant Difference

\begin{tabular}{lccccc}
\hline Anova (Value) & $\begin{array}{c}\text { Sum of } \\
\text { Squares }\end{array}$ & df & Mean Square & F & Sig \\
\hline Between groups & 18.855 & 3 & 6.285 & 7.334 \\
Within groups & 272.526 & 318 & .857 & .001 \\
Total & 291.381 & 321 & & \\
\hline
\end{tabular}

Table 2 shows the results of $\mathrm{F}$ as 7.334, which reflects a significant difference at the .001 level. Less than one time out of one thousand would results similar to this be seen by chance.

In order to determine what pair or pairs of means were significantly different, two tests were performed. First, a Tuckey's Honestly Significantly Different (HSD) Post Hoc Pair-Wise comparison procedure was selected because it divides all obtained means into subgroups and utilizes a standardized range for a comparison of the means. It is based on the principal that the range of any subset of the sample means must exceed a certain value before any of the population means can be considered different. The second test was a least significant difference (LSD). Table 3 shows the results of both tests.

Table 3 shows that the Tukey's HSD Diverger Learning Style preference group's means were significantly lower than the other three at the .01. No other pair-wise comparisons were significant. Results were identical when the LSD was applied.

When sorted by learning style, there was no significant difference in mean grade points (GP) earned for three of the four learning style preferences. Assimilator Style preference learners (3.4), Accommodator Style preference learners (3.1), and Converger Style preference learners (3.3) showed no significant difference at the .01.

When sorted by learning style, there was a significant difference in mean grade points (GP) earned found in one of the four learning style preferences. Diverger Style preference learners (2.7). The mean grade points (GP) earned were significantly lower than the other three learning styles at the .05 level. No other pair-wise comparisons were significant.

The results of the Tuckey's HSD and least significant difference (LSD) shows two homogeneous subsets exist. One subset is comprised of Diverger Style preference learners. The other subset contains the three remaining learning styles, Assimilator, Accommodator, and Converger. Table 4 shows the values determining both subsets. 
Table 3

Results of Tuckey's HSD and Least Significance (LSD) Tests

Multiple Comparisons (Dependent Variable: Value)

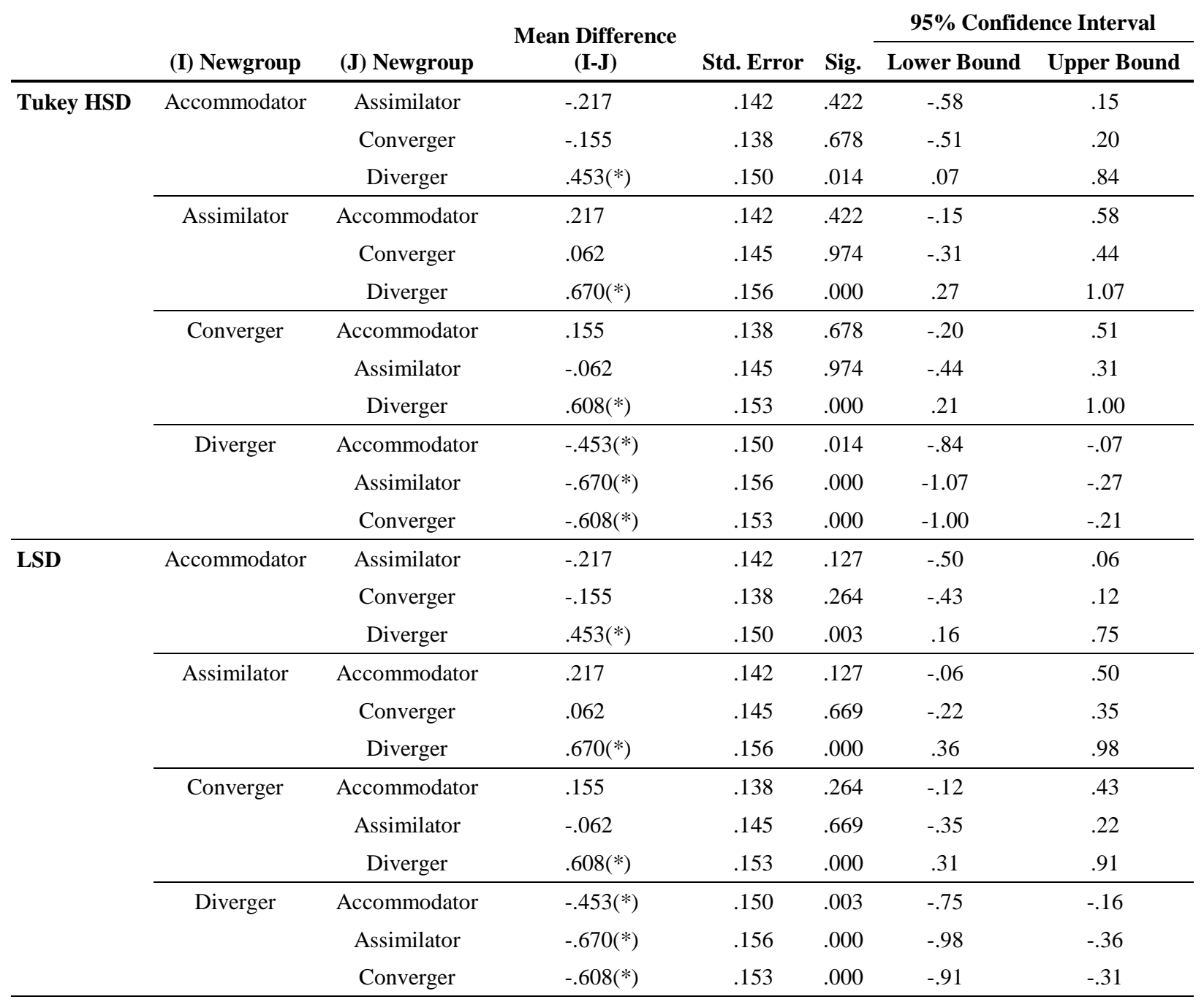

Note: $*$ The mean difference is significant at the .05 level. 
Table 4

Homogeneous Subsets Generated by GPA Conversion Rate

\begin{tabular}{lcccc}
\hline & \multicolumn{3}{c}{ Subset for alpha $=\mathbf{. 0 5}$} \\
\hline Newgroup & $\mathbf{N}$ & $\mathbf{1}$ & $\mathbf{2}$ \\
\hline Divey HSD(a,b) & 64 & 2.70 & 3.15 \\
& Accommodator & 94 & & 3.30 \\
Converger & 86 & & 3.37 \\
Assimilator & 78 & & .457 \\
\hline
\end{tabular}

Note: Means for groups in homogeneous subsets are displayed.

a Uses Harmonic Mean Sample Size $=78.877$.

$\mathrm{b}$ The group sizes are unequal. The harmonic mean of the group sizes is used. Type I error levels are not guaranteed.

Table 5 shows the chi-square calculation to determine whether or not a significant difference existed between learning styles for participants who dropped a course. A chi-square addresses questions about data existing in the form of frequencies, not scores or measurements along some scale (Isaac and Michael 1995).

Table 5

Chi-Square Calculation Determining Whether or not Significant Differences Exist Among Learning Styles for Those Dropping a Course

\begin{tabular}{cccc}
\hline Learning Style & $\begin{array}{c}\text { Completed Course for } \\
\text { Letter Grade }\end{array}$ & $\begin{array}{c}\text { Dropped Course and Did } \\
\text { Not Earn a Letter Grade }\end{array}$ & Total \\
\hline Assimilator & 78 & 2 & 80 \\
Accommodator & 94 & 10 & 104 \\
Converger & 86 & 5 & 91 \\
Diverger & 64 & 5 & 69 \\
\hline
\end{tabular}

Note: Degrees of freedom: 3 ; chi-square $=4.03$; for significance at the .05 level, chi-square should be greater than or equal to 7.82. The distribution is not significant. $p$ is less than or equal to 1 .

Table 5 shows that of the 80 Assimilator Learning Style preference respondents, 2 dropped a course. Of the 104 Accommodator Learning Style preference respondents, 10 dropped a course. Of the 91 Converger Learning Style preference respondents, 5 dropped a course. Of the 69 Diverger Style preference respondents, 5 dropped a course.

The chi-square calculation shows that no significant difference exists among learning styles for those dropping a course.

The findings showed that a significant difference in mean grade points (GP) earned existed for Diverger Style preference learners at .05, but not for the Assimilator, Accommodator, or Converger Style preference learner. The data also showed that no significant difference existed for course completion rate when sorted by learning styles.

\section{CONCLUSIONS}

The results of the study showed that a significant difference existed for Diverger Style preference learners at the .05 level with a lower mean grade points (GP) earned than the other three learning styles. The data also showed that no significant difference existed for course completion rate when sorted by learning styles. 
Conclusion 1: Results of this study indicate that those with a Diverger Learning Style preference generated a significantly lower mean grade points (GP) earned (2.7) than Assimilators (3.4), Accommodators (3.1), and Convergers (3.3). This difference is significant at the .05 level. Additionally, of the twelve participants who received the letter grade F, seven (58 percent) identified themselves as having a Diverger Learning Style preference. Because a meaningful minority of the study's participants, one out of five or 20 percent, had a Diverger Learning Style preference, it can be said this is a group is at a greater risk to do one of two things:

1. Fail a course and not receive credit

2. Fail to obtain content mastery

These results are not surprising as Divergers are best at viewing concrete situations from many different points of view and prefer observation over action. Current DL has limited observation opportunities to address these learning style preferences thereby ignoring the needs of a significant population segment.

Conclusion 2. The data also showed that no significant difference existed for course completion rate when sorted by learning styles. Approximately $93 \%$ percent completed the course for a grade. A vast majority of those participating in this distance learning study achieved successful results. An overwhelming majority (93.6 percent) completed a course and earned credit with 85.7 percent of the participants earning a letter grade of B or better. Not only did participants experience success in the form of earning course credit, more than eight out of ten demonstrated mastery of the material.

Conclusion 3. Only 22 of this study's 344 respondents dropped a course, representing a small percentage (6.4 percent) of those participating in the survey. These results are very different than research conducted by Wang, Foucar-Szocki, and Griffin (2003) indicating the current dropout rate is 26 percent for DL students. One possibility to explain this difference is students who selected themselves to participate in this study (from the general population) are motivated, high achievers committed to finishing the course and doing well. This relates to Conclusion 4 as well.

Conclusion 4. Based on the mean grade points (GP) earned, three of the four possible learning styles demonstrate superior content mastery. Participants identifying themselves as having an Assimilator Learning Style preference (3.4), Accommodator Learning Style preference (3.1), and Converger Learning Style preference (3.3), passed their courses with the letter grade B or better. This compares with (2.7) for the Diverger Learning Style. The results of this study indicate that only 8.7 percent of the participants did not earn course credit or demonstrate course competency, suggesting that a vast majority (93.3 percent) experience success in a distance learning environment.

\section{IMPLICATIONS FOR ACTION}

The study revealed that participants with a Diverger Learning Style preference had significantly lower mean grade points earned at the .05 level of significance. One out of five ( 20 percent) of the study's participants identified themselves as having a Diverger Learning Style preference. This has significant implications for many different types of stakeholders who design, implement, administrate, counsel, and participate in distance learning programs.

To effectively address students with Diverger Learning Style preference needs, this study shows that courses need to address viewing concrete situations from many different points of view and an individual's preference of observation over action. Diverger Style preference learners prefer to be involved in learning style situations where they watch others and develop observations based on their own experiences creates an interesting challenge and opportunity to improve learning in a DL environment. We recommend the following strategies be employed for these "observation" learners in an inherent task oriented medium:

1. To develop concrete experience, course designers should consider using case analysis, scenario development, and recent or real industry problems for discussion, research, and observation. This will 
engage the Diverger by using real problems to gain a sense of involvement in something that is happening as opposed to abstract theoretical or game approaches.

2. Group assignments may increase the Diverger's sense of participation, inter-team observations and increased learning.

3. Discussion boards can be used to allow other groups within the class to post their work for reflection and comment, possibly sparking the Diverger's need to watch and develop their own observations.

The use of real scenarios, cases, group assignments, and shared discovery on discussion boards might increase Divergers' performance in the class by responding to their natural learning preferences.

Several DL experts reviewed and commented on these results. Dr. Kara Wolfe, Assistant Professor and Program Coordinator Hospitality and Tourism Management at NDSU, notes that Divergers are usually sensitive to others and was not surprised they did not perform as well in a DL environment. She suggested that any type of instructional design where Divergers are given an opportunity to focus on their creativity, as well as connect with people, will assist learning in an online environment. Dr. Wolfe agrees that discussion boards are an effective way to reach Divergers and also suggests the use of chat rooms, video chat sessions, or podcasts.

Dr. Seta Whitby, Associate Professor and Program Chairperson of Computer Science and Engineering at the University of La Verne, advocates the utilization of discussion boards when analyzing case studies as being an effective teaching strategy for Divergers and all other learning styles. Dr. Fred Rovai, Professor at Regent University, suggests attention be paid to Problem Based Learning (PBL), specifically case studies.

While it is important to address the needs of all student learning style preferences, these three DL experts agree that two strategies would specifically benefit those with a Diverger Learning Style preference:

1. Increased use of discussion boards to foster reflection

2. Use of case studies to foster observation and analysis

\section{IMPLICATIONS FOR ADMINISTRATORS}

Revealed in this study are implications for college administrators seeking qualitative data to measure the effectiveness of their online learning programs. The study revealed that 20 percent of the participants identified themselves as having a Diverger Learning Style preference. These participants had a statistically significant lower mean grade points earned. Any university seeking to maintain quality instruction and a prominent reputation cannot ignore the fact that 20 percent of their online population is at risk of not obtaining superior content mastery. DL course design and pedagogy needs to address this meaningful minority.

\section{IMPLICATIONS FOR PARTICIPANTS}

Stakeholders attempting to determine whether or not pursuing an MBA in an online environment stand to gain insight from this study. In May of 2007 a Google Search for "MBA's Online " generated 3,950,000 results, indicating a wide variety of existing options to pursue this advanced degree. Additionally, some MBA applicants are paying counselors up to $\$ 3,250$ to help get into the business schools of their choice (Porter 2007). With the price of online MBAs, depending on the school, ranging from $\$ 10,000$ to over $\$ 100,000$ (Littlefield 2007), corporations considering whether or not to subsidize employees pursuing an MBA, or other higher-level training, can use this information to determine whether or not specific individuals may find success in an online learning environment. This study suggests that an MBA candidate with a Diverger Style Learning preference may have difficulty experiencing success in an online environment and save a corporate or personal investment of up to $\$ 100,000$.

\section{IMPLICATIONS FOR COUNSELORS}

Guidance counselors can use this information to recommend, to both students and parents, whether or not an individual may be successful in an online learning environment. 


\section{RECOMMENDATIONS FOR FUTURE RESEARCH}

The dropout rate in this study was lower than data suggested by other studies. Research into the general population (those who did not take the survey, but dropped) would help to see if self-selection affected the drop rate of this study. Researchers could seek out online students who dropped a course, entice them to participate in a learning style preference survey, and determine whether or not significant differences exist in course completion rates when sorted by learning styles on a larger scale.

A replication of this study should be conducted in a different environment. Different data could be generated by using another geographical region or academic discipline.

\section{AUTHOR INFORMATION}

Dr. Nastanski is Dean of the School of Business and Associate Professor of Management and Marketing at Saint Leo University. Prior to joining Saint Leo, he was Executive Director of Business Development and Marketing, for Elcotel, Inc., and held senior executive positions in Schlumberger, a global energy company where he directed operations in Paris, France and several US locations. He also holds a Masters in Business Management from Central Michigan University and a Doctorate in Business Administration from the University of Sarasota. His research interests include the integration of technology and learning and is the author of numerous publications including "From Shanghai to Mumbai", a book centered on Asian business dynamics published by Kendall-Hunt Publishing in 2005.

Dr. Thomas Slick earned his Bachelor of Arts in Social Science from Michigan State University, Master of Arts in Counseling from the University of Redlands, and Educational Doctorate in Organizational Leadership from the University of La Verne. He spent fifteen years as a secondary educational educator and the past five years as a high school guidance counselor. Additionally, he is an Adjunct Professor at California State University San Bernardino and Co-Chair for the Cal-PASS East Valley Guidance Counseling Committee. His research interests include the evaluating the impact of learning styles on student performance and the ability to improve learning through pre-assessment and counseling.

\section{REFERENCES}

1. Anderson, D. M., and Carol J. Haddad. 2005. Gender, voiced, and learning in online course environments. Journal of Asynchronous Learning Networks 9, no. 1: 1-16.

2. Aragon, Steven R., Scott D. Johnson, and Najmuddin Shaik. 2002. The influence of learning style preferences on student success in online versus face-to-fact environments. American Journal of Distance Education 16, no. $4: 227-44$.

3. Baab, Lujean. 2004. Effects of selected factors on students' sense of classroom community in distance learning courses. Ed.D. diss., Pepperdine University, Malibu, CA.

4. Bates, A. W. T. 1995. Technology: Open learning and distance education. New York: Routledge.

5. Bender, D. M., B. Jeanneane Wood, and Jon D. Vredevoogd. 2004. Teaching time: distance education versus classroom instruction. The American Journal of Distance Education 182: 103-14.

6. Berge, Zane L. 2002. Active, interactive, and reflective e-learning. The Quarterly Review of Distance Education 3, no. 2: 181-90.

7. Bernard, Robert M., Aaron Brauer, Philip C. Abrami, and Mike Surkes. 2004. The development of a questionnaire for predicting online learning achievement. Distance Education 25, no. 1: 31.

8. Bernard, Robert M., Phillip C. Abrami, Yiping Lou, Evgueni Borokhovski, Anne Wade, Lori Wozney, Peter Andrew Wallet, Manon Fiset, and Binru Huang. 2004. How does distance education compare with classroom instruction? A meta-analysis of the empirical literature. Review of Educational Research 74, no. 3: 379-439.

9. Bloom, Benjamin S., ed. 1956. Taxonomy of educational objectives: The classification of educational goals, by a committee of college and university examiners. New York: D. McKay Company. 
10. Buck, Thomas L. 2003. An investigation and field dependence-independence and cognitive abilities in a non-linear distance learning environment. Ed.D. diss., Walden University.

11. Bütün, E. 2005. Teaching genetic algorithms in electrical engineering education. International Journal of Electrical Engineering Education 42, no. 3 (July): 223.

12. Carnevale, Dan. 2005. Offering entire degrees online is one key to distance education. Chronicle of Higher Education 51, no. 22: 31.

13. Cassidy, Simon. 2004. Learning styles: An overview of theories, models, and measures. Educational Psychology 24, no. 4: 419-45.

14. Chan, Peng S., and Brad Welebir. 2003. Strategies for e-education. Industrial and Commercial Training 35, no. 4/5: 196.

15. Chernish, William N., Agnes L. De Franco, James R. Linder, and Kim E. Dooley. 2005. Does it matter: Analyzing the results of three different learning delivery methods. The Quarterly Review of Distance Education 6, no. 2: 87-95.

16. Dean, Annie M., and William G. Camp. 1998. Defining and achieving student success: University and faculty and student perspectives. New Orleans, LA: American Vocational Association Convention.

17. DeTure, M. 2004. Cognitive style and self efficacy: Predicting student success in online distance education. The American Journal of Distance Education 18, no. 1: 21-38.

18. Devi, Chandra. 2001. Qualities of a successful online learner. Computimes Malaysia, 30 April.

19. Dickey, Michelle D. 2004. The impact of Web-logs (blogs) on student perceptions of isolation and alienation in a Web-based distance learning environment. Open Learning: The Journal of Open and Distance Learning 19, no. 3: 279-92.

20. Dille, B., and M. Mezack. 1991. Identifying predictors of high risk among community college telecourse students. The American Journal of Distance Education 5, no. 1: 24-35.

21. Du, Yunfei, and Carol Simpson. 2002. Effects of learning styles and class participation on students' enjoyment level in distributed learning environments. Paper presented at the annual conference of the Association for Library and Information Science Education, New Orleans, LA, 15-18 January.

22. Dupin-Bryant, P. A. 2004. Teaching styles of interactive television instructors: A descriptive study. The American Journal of Distance Education 18, no. 1: 39-50.

23. Dzakiria, H. 2005. The role of learning support in open and distance learning: learners' experiences and perspectives. The Turkish Online Journal of Distance Education 62: 16 pages. ERIC, ED 490368.

24. Elias, J., and S. Merriman. 1995. Philosophical foundations of adult education. Malabar, FL: Krieger.

25. Garland, D. K. 2002. Learning style characteristics of the online student: A study of learning styles, learner engagement, and gender. Ed.D. diss., University of Missouri-Columbia.

26. Gibbs, Graham. 2003. Improving student learning through assessment. Journal of Geography in Higher Education 27, no. 2 : 123-32.

27. Goehring, H. J. 1981. Statistical methods in education. Arlington, VA: Information Resource Press.

28. Heady, Judith E. 2000. Assessment - a way of thinking about learning — now and in the future. Journal of Science Teaching 29, no. 6: 415-21.

29. Hergenhahn, B. R., and Matthew H. Olson. 2001. An introduction to theories of learning. Upper Saddle, River, NJ: Prentice-Hall.

30. Hochberg, J. 2006a. Online distance education pedagogy: Emulating the practice of global business. Distance Education 27, no. 1 (May): 129-33.

31. Holmberg, Borje. 1986. Growth and structure of distance education. London: Croom Helm.

32. 1995. Theory and practice of distance education. 2d ed. New York: Routledge.

33. Howell, Scott L., Dwight R. Laws, and Nathan K. Lindsay. 2004. Re-evaluating course completion in distance education: Avoiding the comparison between apples and oranges. The Quarterly Review of Distance Education 5, no. 4: 243-52.

34. Isaac, S. M., and William B. Michael. 1995. Handbook in research and evaluation. San Diego, CA: EdiTS/Educational and Industrial Testing Services.

35. Jefferson, V. G. 2005. A comparison of traditional and nontraditional students taking distance education internet courses. Ed.D. diss., Baylor, University, Waco, TX. 
36. Johnson, S. D., Angela D. Benson, John Duncan, Olga N. Shinkareva, Gail Diane Taylor, and Tod Treat. Distance Learning in Postsecondary Career and Technical Education. St. Paul, MN: University of Minnesota, National Research Center for Career and Technical Education.

37. Kasworm, Carol. 2005. Adult student identity in an intergenerational community college classroom. Adult Education Quarterly 56, no. 1: 3-20.

38. Kim, Hee-Young. 2005. "Can a faceless teacher be close to students?" The lived experience of online instructors in higher education. Ed.D. diss., University of Houston, Houston, TX.

39. Knowles, Malcolm Shepard and Associates. 1984. Andragogy in action. San Francisco: Jossey-Bass.

40. Kolb, A. Y., and D. A. Kolb. 2005. The Kolb Learning style inventory-version 3.1: 205 technical specifications. Boston, MA: Hay Resources Direct.

41. Lee, Y., Marcy Driscoll, and David M. Nelson. 2004. The past, present, and future of research in distance education: Results of a content analysis. The American Journal of Distance Education 18, no. 4: 207-24.

42. Littlefield, J. 2007. Online MBA degree basics. Adult Basic Education. New York: A. C. D. Learning, New York Times Company.

43. Loo, Robert. 2002. A meta-analytic examination of Kolb's learning style preferences among business majors. Journal of Education for Business 77, no. 5 (May-June): 252.

44. McComb, Barbara L., and Donna Varilli. 2005. A learner-centered framework for e-learning. Teachers College Record 107, no. 8: 1582-600.

45. Michlitsch, Joseph F., and Meg Wright Sidle. 2002. Assessing student learning outcomes: A comparative study of techniques used in business school disciplines. Journal of Education for Business 77, no. 3: 12530 .

46. Muilenburg, Lin, and Zane L. Berge. 2005. Student barriers t o online learning: A factor analytic study. Distance Education 26, no. 1: 29-46.

47. NCES. 2003. See U.S. Department of Education. 2003.

48. NEA. 2002. NEA policy statements. Available from http://www2.nea.org/he/ policy13.html; Internet; accessed 25 December 2005.

49. Notar, Charles E., Janell D. Wilson, and Mary K. Montgomery. 2005. A distance learning model for teaching higher order thinking. College Student Journal 30, no. 1: 17-25

50. O'Lawrence, H. 2006. The influences of distance learning on adult learners. Techniques 81: 5.

51. Pattison, Sherri. 1999. A history of the adult distance education movement. Ed.D. diss., Nova Southeastern University.

52. Phillips, Janet M. 2005. Strategies for active learning in online continuing education. Journal for Continuing Education in Nursing 36, no. 2: 77.

53. Phipps, R., and J. Merisotis. 1999. What's the difference? A review of contemporary research on the effectiveness of distance learning in higher education. Washington, DC: Institute for Higher Education Policy.

54. Piaget, Jean. 1977. The development of thought: Elaboration of cognitive structures. New York: Viking.

55. Porter, J. 2007. A booming business in MBA coaches. New York: The McGraw-Hill.

56. Prewitt, Timothy. 1998. The development of distance learning delivery systems. Higher Education in Europe XXIII, no. 2: 187-94.

57. Riding, Richard, and Indra Cheema. 1991. Cognitive styles—an overview and integration. Educational Psychology 11, no. 3-4: 23.

58. Rogers, Carl R. 1969. Freedom to learn. Columbus, OH: Charles E. Merrill.

59. Rovai, A. P., and Jason D. Baker. 2005. Gender differences in online learning: Sense of community, perceived learning, and interpersonal interactions. The Quarterly Review of Distance Education 6, no. 1: 31-44.

60. Simonson, M., S. Smaldino, M. Albright, and S. Zvacek. 2003. Teaching and learning at a distance: Foundations of distance education. 2d ed. Upper Saddle River, NJ: Merrill/Prentice-Hall.

61. Sims, R. D., Graeme Dobbs, and Tim Hand. 2002. Enhancing quality in online learning: Scaffolding planning and design through proactive evaluation. Distance Education 232: 135-48.

62. Thorndike, Edward. 1922. The psychology of arithmetic. New York: Crowell-Collier and Macmillan.

63. Tonkin, S. E. 2003. Predisposing characteristics of learner success in online education. Ph.D. diss., The College of William and Mary in Virginia. 
64. Trotter, A. 2004. Online education. Education Week 24, no. 13: 16.

65. USDLA. 2006. USDLA home. Available from http://www.usdla.org; Internet; accessed 15 February 2006.

66. Vivoda, M. 2005. Distance learning. $R D H$ 25, no. 8: 71-80.

67. Wang, G., D. Foucar-Szocki, D., and O. Griffin. 2003. Departure, abandonment, and dropout of elearning: dilemma and solutions. Saratoga Springs, NY: Maisie Center e-Learning Consortium.

68. White, C. 2005. Contribution of distance education to the development of individual learners. Distance Education 262: 165-81.

69. Willging, Pedro A., and Scott D. Johnson. 2004. Factors that influence students' decision to dropout of online courses. Journal of Asynchronous Learning Networks 8, no. 4 (December). ISSN 1092-8235.

70. Wojciechowski, A., and Louann Bierlein Palmer. 2005. Individual student characteristics: Can any be predictors of success in online classes? Online Journal of Distance Learning Administration VIII, no. II.

71. Zhang, D., and Lina Zhon. 2003. Enhancing e-Learning with interactive multimedia. Information Resources Management Journal 16, no. 4: 1-11.

\section{NOTES}

